\title{
Webinar International: Strategy to start a research \& write a paper, Gain international research collaboration
}

\author{
Evan Afri $^{1)} \mid$ Muhammad Khoiruddin Harahap ${ }^{2)} \mid$ Diding Kusnady $^{3),}$ Surya Hendraputra ${ }^{4)}$ \\ 1,2,3,4) Politeknik Ganesha Medan \\ evanafri@gmail.com | choir.harahap@yahoo.com | kusnadydiding1@gmail.com | \\ surya_hendra_putra@yahoo.com
}

\begin{abstract}
Abstrak: Kolaborasi adalah proses yang melibatkan banyak orang, kelompok, dan organisasi untuk mencapai hasil yang diharapkan. Kerja sama dapat mencapai visi bersama, mencapai hasil yang positif bagi audiens yang mereka layani, dan membangun sistem yang saling berhubungan untuk memecahkan masalah dan peluang. Literasi informasi pembelajaran merupakan metode pembelajaran yang dirancang untuk memperkaya informasi untuk membantu menyelesaikan tugas kelas. Sementara itu, menurut pakar psikologi pendidikan, keterampilan literasi informasi siswa lebih mengacu pada kemampuan bersaing dan kemandirian daripada ketergantungan. Metode kegiatan pengabdian ini dilakukan dengan Webinar dengan narasumber dari dalam negeri dan luar negeri. Hasil yang didapatkan pada penelitian ini masih mengacu pada tingkat kepuasan audiens terhadap materi dan teknis penyelenggaraan dengan hasil bahwa audiens cukup puas. Kegiatan seperti ini perlu diadakan lebih sering dan konsisten dengan mencapai tema tema yang bersinggungan dengan kerjasama antara bangsa.
\end{abstract}

Kata Kunci: Kolaborasi luar negeri; webinar; penelitian tingkat internasional

\section{Pendahuluan}

Definisi Kolaborasi merupakan proses partisipasi beberapa orang, kelompok, dan organisasi yang bekerja sama untuk mencapai hasil yang diinginkan. Kolaborasi menyelesaikan visi bersama, mencapai hasil positif bagi khalayak yang mereka layani, dan membangun sistem yang saling terkait untuk mengatasi masalah dan peluang. Kolaborasi juga melibatkan berbagi sumber daya dan tanggung jawab untuk secara bersama merencanakan, melaksanakan dan mengevaluasi program-program untuk mencapai tujuan bersama. Anggota kolaborasi harus bersedia untuk berbagi visi, misi, kekuatan, sumber daya dan tujuan.

Proses pembelajaran di perguruan tinggi membutuhkan kemampuan kogintif tingkat tinggi, seperti kemampuan sintesis dan analisis. Tidak hanya sekedar pengetahuan faktual ataupun aplikasi sederhanah dari berbagai formula atau prinsip. Mahasiswa diharapkan mampu bernalar dengan baik dan mengekspresikan hasil penalarannya secara tertulis sistematis dan ketat (rigorous) sehingga dapat mencapai kemampuan literasi informasi. Kemampuan ini dapat diperoleh melalui sistem pembelajaran kolaboratif.

Literasi informasi dalam kontek pembelajaran di perguruan tinggi menurut Zarkowi dalam Bahren adalah metode pembelajaran yang berorientasi pengayaan informasi atau penguasaan materi untuk membantu menyelesaikan tugas-tugas perkuliahan. Sementara menurut para pakar psikologi pendidikan bahwa kemampuan literasi informasi untuk mahasiswa lebih merujuk pada kemampuan untuk berkompetisi (competition) dan kemandirian (independence) ketimbang ketergantungan (independence) (HAQQI, 2017).

Wabah virus Corona yang muncul pada tahun 2019 telah menimbulkan banyak korban yang meninggal di seluruh dunia. Indonesia adalah salah satu negara yang turut merasakan keganasan dari virus yang berawal dari Wuhan tersebut. Dan pada akhirnya, pemerintah Indonesia secara resmi 
menetapkan bahwa wabah ini merupakan bencana nasional dan untuk penanganan kasus ini, maka pemerintah membentuk tim atau gugus penanganan Covid-19 (Telaumbanua, 2020).

Wabah yang begitu cepat menyebar luas ke seluruh wilayah Indonesia, memaksa pemerintahan harus mengambil kebijakan guna memutus mata rantai penyebaran virus tersebut. Mulai dari long distance, bahkan sampai peraturan PSBB yang diberlakukan di beberapa wilayah di Indonesia (Fauzi, 2020). Wabah ini berdampak bagi seluruh aktifitas kehidupan masyarakat, banyak aktifitas yang terganggu atau bahkan harus berhenti total. Wabah ini juga turut merubah sistem pembelajaran pada dunia pendidikan, wabah ini seolah mempercepat penerapan pembelajaran abad 21. Selama ini pendidikan dilaksanakan secara konvensional menjadi sistem pembelajaran dari rumah masingmasing berbasis e-learning.

Situasi ini tentunya sangat membatasi gerak kita untuk melakukan kegiatan penelitian atau pengabdian yang selama ini kita harus turun langsung ke lapangan. Namun, waktu yang sangat baik ini sangat lah penting bagi kita untuk mengetahui strategi melakukan penelitian kolaborasi dengan berbagai Perguruan Tinggi di Indonesia dan Luar Negeri.

Banyaknya dosen yang belum paham bagaimana cara melakukan kolaborasi riset, karena hal ini sangatlah bermanfaat bagi banyak orang. Untuk itu sangatlah menarik apabila di saat WFH kita memanfaatkan waktu yang ada untuk merancang sebuah kegiatan webinar international yang bisa bermanfaat bagi masyarakat luas, khusus nya dosen.

\section{Realisasi Kegiatan}

Kegiatan dilakukan dengan metode pembelajaran secara daring atau diskusi daring yang sering disebut dengan Webinar. Kegiatan berlangsung pada sabtu, 3 April 2021 mulai dari 14.00 Wib sd 17.00 Wib lewat media Zoom yang didokumentasikan pada ITC Polgan Youtube Channel (Polgan, 2021). Narasumber utama ada dua orang yaitu Adjunt Prof. Mario di Nardo dari University of Naples Frederico II, Italy dengan tema How to write a paper dengan acuan pada karya ilmiah terindex Scopus, dan pembicara berikutnya adalah Prof. Prof. Dr. Ir. Marsudi Wahyu Kisworo dengan membawakan thema Building Successful International Research Collaboration: Challenges and Opportunities

Kegiatan ini diprakarsai oleh Tim Kepanitiaan Politeknik Ganesha Medan dengan ketua Panitia Bpk. Evan Afri dan Wakil ketua Muhammad Khoiruddin Harahap beserta tim lainnya yang dikukuhkan oleh SK Direktur Politeknik Ganesha Medan dengan nomor SK : 434/DIR/SK/POLGAN/2021 yang ditandatangani oleh Direktur Politeknik Ganesha Medan, bapak Diding Kusnady, S. Pd, MM tertanggal 21 Januari 2021.

Kegiatan ini direstui dan disambut dengan sangat baik oleh LLDIKTI Wilayah 1 Sumatera Utara, hal ini tertuang pada antusiasme dan kata sambutan dari ketua LLDIKTI Wilayah 1 Sumatera Utara yaitu Bapak Prof. Ibnu Hajar, M. Si yang berperan sebagai keynote Speaker pada kegiatan tersebut.
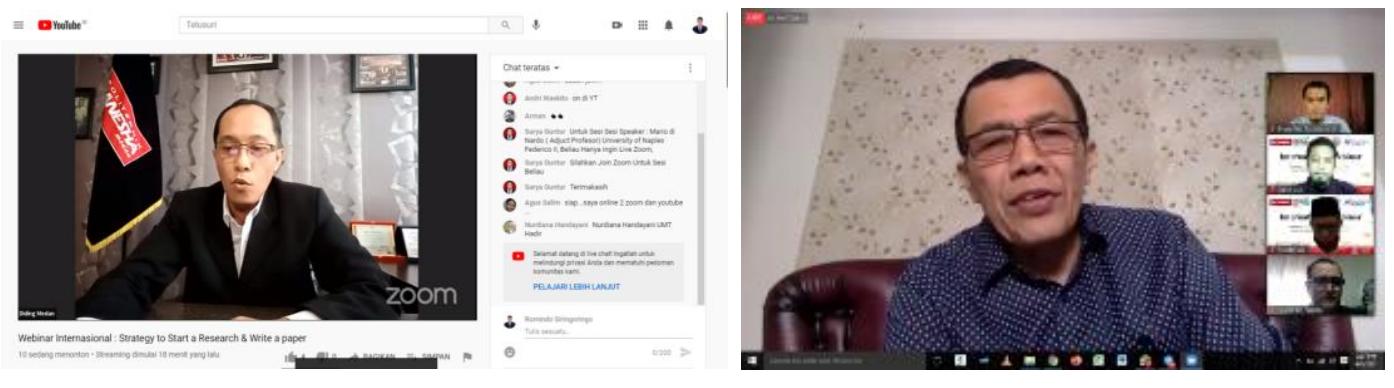

Gambar 1: Kata sambutan Direktur Politeknik Ganesha dan Keynote Speaker Prof. Ibnu Hajar M. Si 
Dedikasi Sains dan Teknologi

Jurnal Pengabdian Masyarakat

Vol: 1, No: 1, Mei 2021

Doi : https://doi.org/10.47709/dst.v1i1.954
Submitted : 1 Mei 2021

Accepted : 5 Mei 2021

Published : 7 Mei 2021
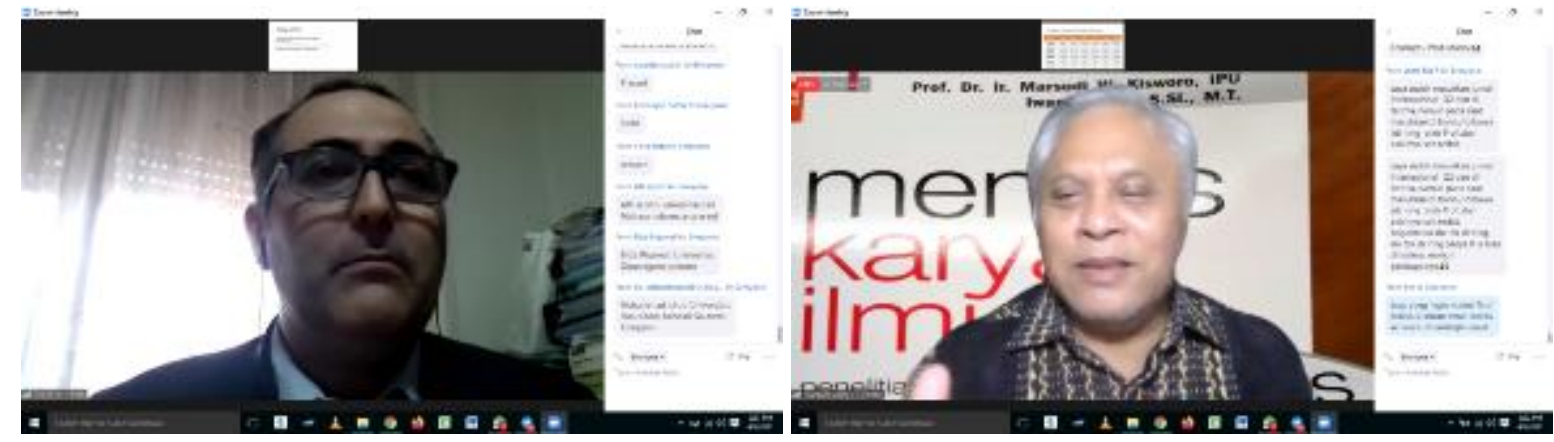

Gambar 2: Narasumber Prof Adjunt, Mario di Nardo dan Prof. Dr. Ir. Marsudi Wahyu Kisworo

\section{Hasil}

Kegiatan ini diikuti oleh 1540 partisipan dari berbagai institusi terutama Perguruan Tinggi dari seluruh wilayah Indonesia. Komposisi peserta berdasarkan formulir isian terdapat partisipan dari kalangan dosen dengan angka 85,4\% seperti pada gambar 3 dibawah ini.
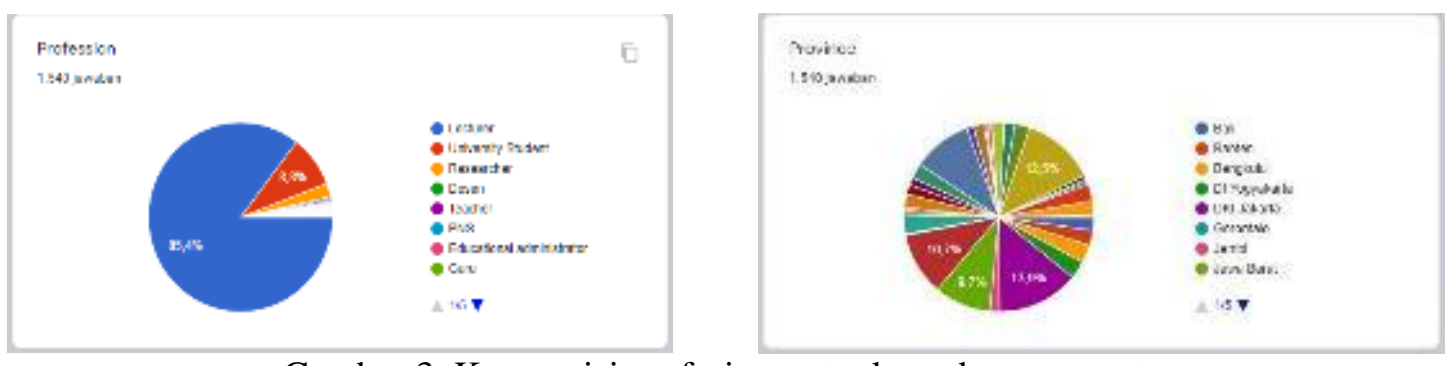

Gambar 3, Komposisi profesi peserta dan sebaran peserta.

Berikut tangkapan layar kegiatan berupa peserta kegiatan, narasumber dan materi yang disampaikan serta sertifikat yang diberikan kepada partisipan webinar.
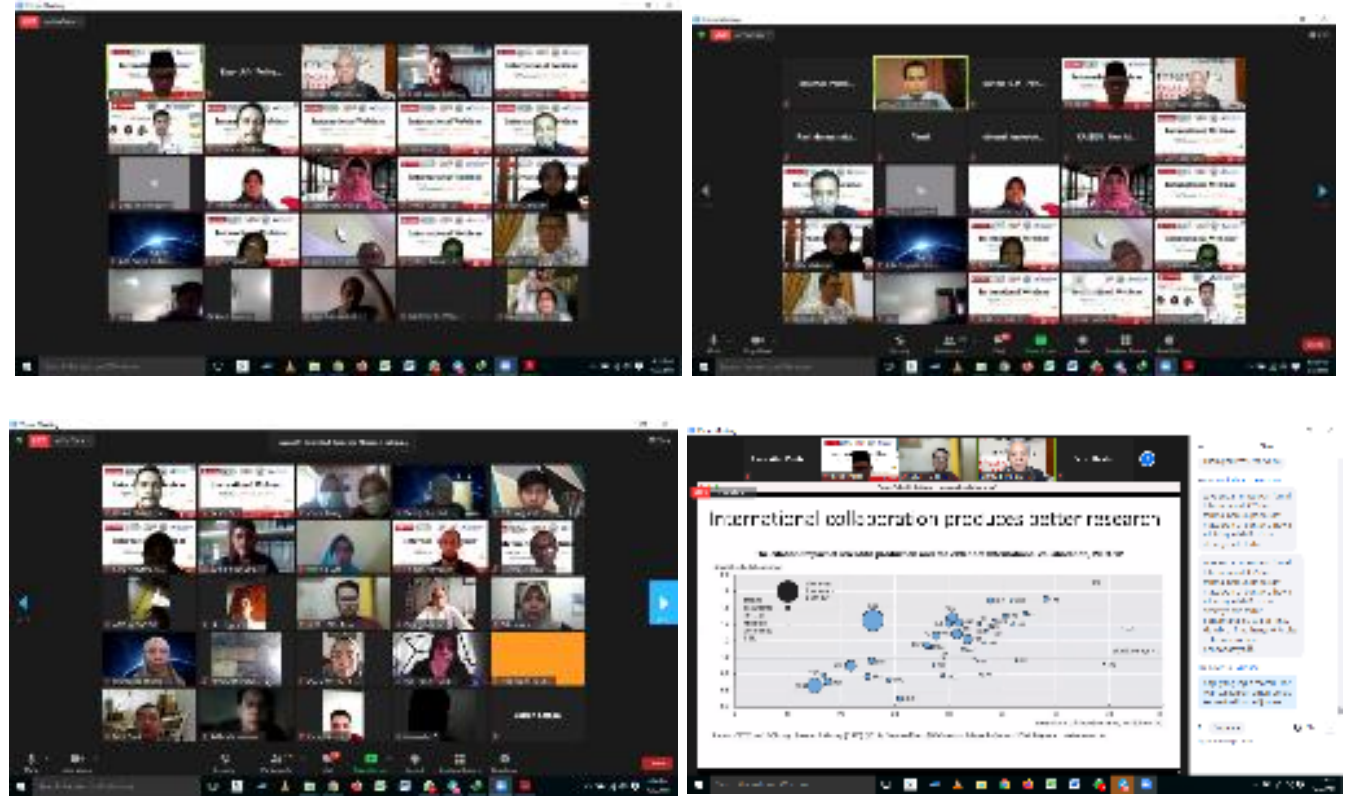


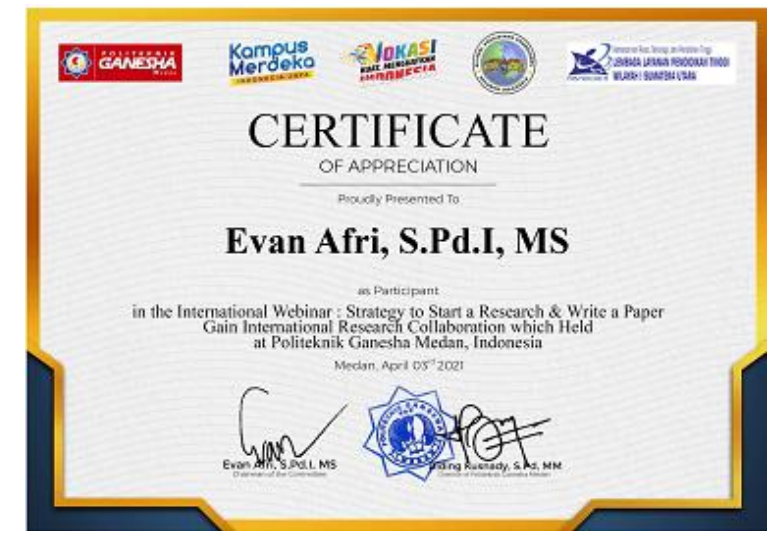

Gambar 4. Dokumen tangkapan layar dan sertifikat peserta webinar

\section{Kesimpulan}

Kegiatan ini bertujuan agar para dosen dan peneliti membuka peluang melakukan kerjasama internasional. Antusiasme masyarakat dengan kegiatan ini cukup bagus yang diakumulasi dari evaluasi umpan balik yang menyatakan bahwa $87.5 \%$ menyatakan puas. Setelah kurun waktu 30 hari setelah kegiatan ini, panitia menjajaki kepada narasumber tentang terjadinya komunikasi setelah kegiatan dengan partisipan dan narasumber. Perlunya penjajakan peningkatan kuantitas publikasi ilmiah di tingkat internasional.

\section{$\underline{\text { Daftar Pustaka }}$}

Fauzi, A. (2020). IMPLEMENTASI PEMBATASAN SOSIAL BERSKALA BESAR, SEBUAH KEBIJAKAN PUBLIK DALAM PENANGANAN PANDEMI COVID-19. JIANA: JURNAL ILMU ADMINISTRASI NEGARA, 174-178.

HAQQI, A. (2017). COLLABORATIVE LEARNING : Model Pembelajaran Dalam Upaya Meningkatkan Literasi Informasi Mahasiswa Jurusan Ilmu Perpustakaan dan Informasi Melalui Belajar secara Kolaboratif. Baitul al 'Ulum : Jurnal Ilmu Perpustakaan dan Informasi, 1-22.

Polgan, I. (2021, April 3). ICT Polgan Youtube Channel. Retrieved from https://www.youtube.com/watch?v=JiSsab4kEfU

Telaumbanua, D. (2020). Urgensi Pembentukan Aturan Terkait Pencegahan Covid-19 di Indonesia. Qalamuna - Jurnal Pendidikan, Sosial, dan Agama, 59-70. 